\title{
STRATEGI PERUBAHAN PERILAKU PEMILIHAN SEPTIC TANK DI PERMUKIMAN DAERAH RENDAH \\ (Studi Kasus Kota di Banjarmasin)
}

\author{
Juanda A. Zuraini \\ Poltekkes Kemenkes Banjarmasin Jurusan Kesehatan Lingkungan \\ Jl. H. Mistar Cokrokusumo No.1A Banjarbaru Kalimantan Selatan 70714 \\ E-mail: juandabrawijaya@gmail.com
}

\begin{abstract}
Strategy of Septic Tank Choice Behavioral Change in Low Area Settlement (Case Study in Banjarmasin City). The coverage of liquid waste management service in Banjarmasin City by using septic tank through off site handling as well as in site handling according to the National Standard of Indonesia to date can serve approximately 6-7\% of all residents of Banjarmasin. This means that individual use of septic tank is around $93-94 \%$ of all residents. This study was done in Banjarmasin City, South Kalimantan, including 5 districts of Central Banjarmasin, East Banjarmasin, West Banjarmasin, North Banjarmasin, and South Banjarmasin. The study was done in April 2014 until February 2016. The population for behavioral change development strategy sub system was originated from Public Health Office, Public Works Service, Drainage and Water Resource Office, Living Environment Department, Local Company of Wastewater Management, and public figures. The results showed that according to SWOT analysis, strategy of septic tank choice behavior development in Banjarmasin City settlement was in G room of quadrant IV, so the strategy used was conglomerate diversification strategy through the change of guided behavior predisposing factors to adoption phase, enabling factor of change in understanding of the availability of standardized disposal facilities, and amplifier factor needed an optimization of local regulation socialization in Banjarmasin City related to fecal disposal.
\end{abstract}

Keywords: Behavioral Change; Septic Tank Choice; SWOT Analysis.

\begin{abstract}
Abstrak: Strategi Perubahan Perilaku Pemilihan Septic Tank di Permukiman Daerah Rendah (Studi Kasus Kota di Banjarmasin). Cakupan pelayanan pengelolaan limbah cair di Kota Banjarmasin menggunakan septic tank dengan pengolahan terpisah (off site handling) maupun pengolahan setempat (in site handling) sesuai SNI sampai saat ini dapat melayani kurang lebih 6-7\% dari seluruh warga kota Banjarmasin, yang berarti bahwa penggunaan septic tank individual antara 93-94\% dari keseluruhan warga masyarakat. Penelitian ini dilaksanakan di kota Banjarmasin Kalimantan Selatan, meliputi 5 Kecamatan yaitu Banjarmasin Tengah, Banjarmasin Timur, Banjarmasin Barat, Banjarmasin Utara dan Banjarmasin Selatan. Waktu penelitian dilaksanakan bulan April 2014-Februari 2016. Populasi untuk sub sistem strategi pengembangan perubahan perilaku berasal dari Dinas Kesehatan Kota Banjarmasin, Dinas Pekerjaan Umum Kota Banjarmasin, Dinas Drainase dan Sumber Daya Air, Badan Lingkungan Hidup Kota Banjarmasin, PD-PAL Banjarmasin, dan tokoh masyarakat. Hasil penelitian menunjukkan strategi pengembangan perilaku pemilihan septic tank di permukiman kota Banjarmasin berdasarkan analisis SWOT berada pada kuadran IV ruang G sehingga strategi yang digunakan adalah conglomerate diversification strategy melalui perubahan pada faktor predisposisi perilaku terpimpin ke tahap adopsi, faktor pemungkin perubahan pemahaman terkait ketersediaan prasarana dan sarana pembuangan tinja yang sesuai standar dan faktor penguat diperlukan optimalisasi sosialisasi peraturan daerah Kota Banjarmasin yang ada terkait pembuangan tinja.
\end{abstract}

Kata Kunci: Perubahan Perilaku; Pemilihan Septik tank; Analisis SWOT. 


\section{PENDAHULUAN}

Kepemilikan terhadap fasilitas tempat buang air secara nasional menurut (Susenas) 2007 sebesar 59,86\% terdiri dari $42,79 \%$ jenis kloset leher angsa dan $29,41 \%$ telah memiliki septik tank [1]. Menurut Susenas (2011) menyatakan bahwa proporsi rumah tangga dengan akses terhadap fasilitas sanitasi dasar yang layak, di perkotaan dan pedesaan sebesar 55,60\% sedangkan target Millineum Development Goals (MDGs) tahun 2015 sebesar $62,41 \%$ artinya masih di bawah angka target MDGs. Proporsi rumah tangga dengan akses terhadap fasilitas sanitasi dasar layak 72,54\% di perkotaan dan $38,97 \%$ di pedesaan dengan target MDGs 2015 perkotaan $76,82 \%$ dan pedesaan $55,55 \%$ artinya baik di perkotaan maupun pedesaan masih berada di bawah target MDGs [2].

Sedangkan jenis kloset yang digunakan rumah tangga menurut Riset Kesehatan Dasar (Riskesdas) tahun 2010, di Provinsi Kalimantan Selatan dibandingkan prosentase nasional dengan leher angsa $(85,6 \%)$ nasional $(77,58 \%)$, dengan pelengsengan $(8,2 \%)$ nasional $(6,37 \%)$, cubluk/cemplung (5,2\%) nasional $(14,32 \%)$, dan tidak memiliki kloset $\quad(1,0 \%)$ nasional $(1,73 \%)$. Berdasarkan tempat pembuangan tinja di Provinsi Kalimantan Selatan dibandingkan nasional menggunakan septik tank $(50,1 \%)$ nasional $(59,3 \%)$, Saluran Pembuangan Air Limbah(4,1\%) nasional $\quad(2,9 \%)$ memanfaatkan kolam/empang $(0,8 \%)$ nasional $(4,3 \%)$, memanfaatkan sungai/danau (31,8\%) nasional 16,4\%, lubang tanah 12,2\% nasional 11,7\%, pantai/kebun 0,9\% nasional (4,3\%). Prosentase akses pembuangan tinja yang layak di Provinsi Kalimantan Selatan, tidak ada aksesyang layak $(49,1 \%)$ dan nasional $(44,5 \%)$. Rumah tangga menurut cara buang air besar sesuai WHO UNICEF untuk di Provinsi Kalimantan Selatan, improved (penggunaan sendiri, jenis kloset latrine dan pembuangan akhir tinja dengan septic tank 46,8\% nasional 51,5\%, shared (penggunaan bersama/umum, jenis kloset latrine dan pembuangan akhir tinja denganseptic tank) 6,1\% nasional 6,7\%, unimproved (jenis kloset plengsengan atau cemplung) 30,0\% nasional 25\% dan open depecation(tidak menggunakan sarana pembuangan kotoran atau tidak menggunakan kloset atau Buang Air Besar sembarangan) $17 \%$ dan nasional 17,2\%.Kondisi pemilikan sarana jamban sehat pada rumah tangga di kota Banjarmasin dari 129.390 (79,6\%) rumah yang diperiksa, keluarga yang memiliki jamban 86.993 rumah $(67,2 \%)$ sedangkan dari 86.993 rumah tersebut dengan kondisi jamban dikategorikan sehat 57.396 rumah (66\%) [3].

Perilaku pembuangan tinja berhubungan dengan penurunan kualitas lingkungan fisik khusus air, dan juga kasus penyakit diare (water borne diseases) juga sangat berhubungan erat dengan pemanfaatan air untuk keperluan sehari-hari. Pemanfaatan air yang tidak saniter/tercemar mikroorganisme pathogen penyebab diare dan didukung pola pengolahan makanan dan minuman yang tidak aman, serta personal hygiene yang tidak baik berakibat peningkatan kasus penyakit diare. Sebagian besar perilaku masyarakat belum mengarah pada upaya pencegahan penyakit, tetapi masih mengarah pada penyembuhan penyakit [4]. Ketersediaan air bersih Odd Ratio (OR) 4,026 kali berisiko terhadap diare, ketersediaan jamban yang tidak memenuhi syarat (OR) 3,754 kali dan perilaku ibu memberi makan balita (OR) 3,377 kali.

Kota Banjarmasin sebagai salah satu permukiman kota yang berada pada lahan berair, rawa-rawa/berpaya-paya dengan ketinggian rata-rata 0,16 meter di bawah permukaan laut. Pada waktu air pasang hampir seluruh wilayah digenangi air, pengaruh musim hujan dan musim kemarau curah hujan rata-rata $\mathrm{mm} /$ bulan, curah hujan rata-rata 3 tahun (2012-2014) terakhir $189.35 \mathrm{~mm}, 267$ $\mathrm{mm}$ dan $168 \mathrm{~mm}$, curah hujan tertinggi bulan Desember 2014 sebesar $361 \mathrm{~mm}$, sedangkan jumlah hari hujan 14 hari/bulan, 17 hari/bulan dan 9 hari/bulan, jumlah hari hujan 108 hari pada tahun 2014 , suhu rata-rata $27.9{ }^{\circ} \mathrm{C}$ 
dengan kelembaban relatif rata-rata $\mathrm{RH}$ $82 \%$ [1].

Kasus diare insidens rate 10 tahun terakhir cenderung meningkat [3], sedangkan data terakhir pada bayi umur < 28 hari terdapat 55 kasus termasuk urutan ke 3, pada bayi umur 28 hari - 1 tahun diare termasuk urutan ke 2 dengan jumlah kasus 2.154 orang, pada anak umur 1 - 4 tahun urutan ke 2 dengan jumlah kasus 4.972 kasus, pada umur $>65$ tahun 628 kasus [1], sementara jika dibandingkan cakupan air bersih di kota Banjarmasin sampai saat ini (2015) 99,8\% menggunakan air PDAM.

Pengelolaan limbah cair termasuk pengelolaan tinja telah dilakukan oleh pemerintah kota Banjarmasin berupa 1 . aspek pengelolaan teknis yaitu penanganan di luar rumah (offsite handling) yakni a). dengan adanya pengolahan terpadu terintegrasi dengan jaringan pengolahan oleh PD-PAL Banjarmasin dengan 7 (tujuh) unit IPAL yang dimiliki dengan cakupan pelayanan 6.530 satuan sambungan rumah dan 28 satuan sambungan niaga; b). pengolahan terintegrasi denganseptic tank komunal yang telah dibangun dengan cakupan pelayanan 230 satuan sambungan rumah pada tahun 2015; dan penanganan di dalam rumah tangga (insite handling) seperti pemanfaatan septic tank individual telah dilakukan.

Upaya pemerintah kota Banjarmasin dalam rangka perbaikan pengelolaan tinja di permukiman melalui percontohan penggunaan septic tank terapung (modifikasi) sebanyak 30 unit di daerah Banjarmasin Tengah merupakan bantuan dari Dinas Sumber Daya Air \& Drainase Kota Banjarmasin, tetapi harapan agar terjadi peningkatan jumlah secara mandiri oleh masyarakat tidak terpenuhi permasalahan pengelolaan tinja terutama pemenuhan syarat-syarat konstruksi septic tank sebagian besar belum terpenuhi., diperlukan upaya komprehensif dan holistik untuk pengelolaan tinja khususnya pemanfaatan septic tank yang saniter.
Disamping aspek teknis diatas juga poin ke 2. aspek non teknis, pemerintah kota Banjarmasin yaitu telah menerbitkan minimal 3 (tiga) Peraturan daerah (Perda) kota Banjarmasin yang mengarah pada upaya perbaikan pengelolaan limbah cair termasuk pengelolaan tinja yakni Perda kota Banjarmasin nomor 7 tahun 2010 tentang ijin pembuangan dan pengolahan limbah cair, Perda kota Banjarmasin nomor 6 tahun 2013 tentang perumahan di kota Banjarmasin dan Perda kota Banjarmasin nomor 5 tahun 2014 tentang pengelolaan limbah domestik.

Cakupan pelayanan dari penanganan pengelolaan limbah cair di Kota Banjarmasin termasuk pemilihan septic tank dengan pengolahan terpisah (off site handling) maupun pengolahan setempat (in site handling) dengan septic tank sesuai SNI, sampai saat ini dapat melayani kurang lebih $6-7 \%$ dari seluruh warga kota Banjarmasin, yang berarti bahwa penggunaan septic tank individual antara $93-94 \%$ dari keseluruhan warga masyarakat.

Sementara kondisi konstruksi septic tank individual yang dibangun dan digunakan oleh warga masyarakat tersebut diindikasikan tidak memenuhi syarat-syarat teknik septic tank sesuai standard SNI 03-2399-2002 mengenai perencanaan septic tank [5]. Pemanfaatan septic tank saniter sesuai SNI 03-23992002 [6] diharapkan berkontribusi positif terhadap penurunan pencemaran air permukaan, dan sekaligus pencegahan dampak turunannya salah satunya prevalensi diare. Kualitas air permukaan di sekitar permukiman kota Banjarmasin sangat erat hubungannya dengan sistem pengelolaan tinja yang digunakan masyarakat.

Pola pemecahan dengan pendekatan sistem dalam rangka berfikir menyeluruh dan holistik sehingga dapat memberikan gambaran keseluruhan permasalahan dengan jelas serta menyederhanakan kompleksitas permasalahan sehingga diperoleh komponen dominan. Pendekatan sistem 
menganalis mekanisme, pola dan kecenderungan sistem berdasarkan analisis struktur dan perilaku, dinamis, berubah cepat dan mengandung ketidakpastian dengan menyederhanakan permasalahan yang dominan. Akhirnya diharapkan terjadi perilaku dalam pemilihan pengelolaan tinja yang saniter, baik pengolahan terpisah (off site handling) maupun pengolahan setempat (on site handling)di kota Banjarmasin dapat tercapai.

Untuk dapat merumuskan kebijakan yang akan dilakukan dalam upaya pengembangan perubahan perilaku masyarakat dalam pemilihan pengelolaan tinja di permukiman kota Banjarmasin diperlukan alat analisa dalam hal ini menggunakan SWOT yang merupakan salah satu tehnik analisis yang dapat digunakan untuk menginterpretasikan perencanaan. SWOT memperhitungkan faktor-faktor internal dan faktor-faktor eksternal berupa penggalian kekuatan dan kesempatan sebagai faktor positif dan kelemahan dan ancaman sebagai faktor negatif. Prinsip SWOT bahwa strategi yang memanfaatkan kekuatan dan kesempatan; strategi untuk mengatasi ancaman yang ada; strategi untuk memperbaiki kelemahan yang ada. SWOT dapat diartikan sesuai dengan konsep: $S$ (Strength/Kekuatan): suatu keadaan atau kondisi yang ada/hal sudah baik; W (Weakness/Kelemahan): suatu keadaan atau kondisi yang merupakan kelemahan atau masalah;

(Oppurtunities/Kesempatan): suatu keadaan atau kondisi yang ada atau yang akan terjadi yang dianggap sebagai peluanguntuk dimanfaatkan untuk pengembangan perubahan perubahan perilaku dan $\mathrm{T}$ (Threats/Ancaman): suatu keadaan atau kondisi yang ada atau yang akan terjadi di dalam atau di sekitar daerah yang dianggap dapat menghambat atau mengancam pengembangan perubahan perubahan perilaku.

\section{BAHAN DAN CARA PENELITIAN}

Untuk merumuskan strategi pengembangan perilaku pemilihan septic tank sebagai implikasi penelitian dilakukan analisis Strenght Weakness Opportunity Threath (SWOT) dengan External Factor Analysis System (EFAS) dan Internal Factor Analysis System (IFAS) untuk menganalisis kekuatan, kelemahan, peluang dan ancaman dalam pengembangan perilaku pemilihan septic tank di permukiman kota Banjarmasin.

Penelitian ini dilaksanakan di kota Banjarmasin Kalimantan Selatan, meliputi 5 Kecamatan yaitu Banjarmasin Tengah, Banjarmasin Timur, Banjarmasin Barat, Banjarmasin Utara dan Banjarmasin Selatan. Waktu penelitian dilaksanakan bulan April 2014-Februari 2016. Populasi untuk sub sistem strategi pengembangan perubahan perilaku berasal dari instansi pemerintah kota : Dinas Kesehatan Kota Banjarmasin, Dinas Pekerjaan Umum Kota Banjarmasin, Dinas Drainase dan Sumber Daya Air, Badan Lingkungan Hidup Kota Banjarmasin, PD-PAL Banjarmasin, dan tokoh masyarakat.

Teknik pengumpulan data persepsi strategi pengembangan perubahan perilaku dari pendapat responden instansi terkait, tokoh masyarakat, dengan wawancara terstruktur. Data sekunder terkait penelitian ini diperoleh dari instansi-instansi: Biro Pusat Statistik (BPS) Provinsi Kalimantan Selatan, BPS Kota Banjarmasin, Badan Lingkungan Hidup Daerah Provinsi Kalimantan Selatan, Badan Lingkungan Hidup Kota Banjarmasin, Dinas Kesehatan Provinsi Kalimantan Selatan, Dinas Kesehatan Kota Banjarmasin, Dinas Pekerjaan Umum Provinsi Kalimantan Selatan, Dinas Sumber Daya Air dan Drainase Kota Banjarmasin, PD-PAL Banjarmasin.

\section{HASIL PENELITIAN DAN PEMBAHASAN}

Untuk dapat merumuskan kebijakan yang akan dilakukan dalam upaya pengembangan perubahan perilaku masyarakat dalam pemilihan septik tank di permukiman kota Banjarmasin diperlukan alat analisa dalam hal ini menggunakan SWOT yang merupakan salah satu tehnik analisis yang dapat digunakan untuk menginterpretasikan perencanaan. SWOT memperhitungkan faktor-faktor internal dan faktor-faktor 
eksternal berupa penggalian kekuatan dan kesempatan sebagai faktor positif dan kelemahan dan ancaman sebagai faktor negatif. Prinsip SWOT bahwa: strategi yang memanfaatkan kekuatan dan kesempatan; strategi untuk mengatasi ancaman yang ada; strategi untuk memperbaiki kelemahan yang ada. SWOT dapat diartikan sesuai dengan konsep: $\mathrm{S}$ (Strength/Kekuatan): suatu keadaan atau kondisi yang ada/hal sudah baik; W (Weakness/Kelemahan): suatu keadaan atau kondisi yang merupakan kelemahan atau masalah;

(Oppurtunities/Kesempatan): suatu keadaan atau kondisi yang ada atau yang akan terjadi yang dianggap sebagai peluanguntuk dimanfaatkan untuk pengembangan perubahan perubahan perilaku; $\mathrm{T}$ (Threats/Ancaman): suatu keadaan atau kondisi yang ada atau yang akan terjadi di dalam atau di sekitar daerah yang dianggap dapat menghambat atau mengancam pengembangan perubahan perubahan perilaku.

Perilaku bahwa tindakan individu dan kelompok dipengaruhi oleh 3 (tiga) sistem, yaitu sistem sosial, sistem budaya, dan sistem kepribadian masing-masing individu.Kita dapat mengkaitkan individu dengan sistem sosialnya melalui status dan perannya. Dalam setiap sistem sosial individu menduduki suatu tempat (status) tertentu dan bertindak (berperan) sesuai dengan norma atau aturan yang dibuat oleh sistem tersebut dan perilaku individu ditentukan oleh kepribadiannya. Untuk dapat itu diperlukan perubahan sosial, menurut Soemardjan, perubahan sosial meliputi segala perubahan-perubahan pada lembaga kemasyarakatan di dalam suatu masyarakat yang mempengaruhi sistem sosialnya, termasuk di dalamnya nilai-nilai, sikap dan pola perilaku kelompok-kelompok dalam masyarakat. Studi mengenai perubahan sosial harus dimulai dengan studi struktur sosial terlebih dahulu, struktur sosial adalah sebagai tatanan atau susunan sosial yang membentuk kelompok-kelompok sosial dalam masyarakat yang dapat tersusun secara vertikal maupun horizontal atau dapat juga diartikan sebagai cara bagaimana suatu masyarakat terorganisasi dalam hubungan yang dapat diprediksikan melalui pola perilaku berulang antar individu dan antar kelompok dalam masyarakat tersebut, dengan demikian upaya perubahan perilaku masyarakat terkait pengelolaan tinja di permukiman kota Banjarmasin dibutuhkan perubahan sosial. Mengingat dinamika yang terjadi dalam sistem sosial sebagai bagian dalam struktur sosial. Agar sistem sosial dapat bekerja dengan baik minimal 4 fungsi yang harus terintegrasi: Adaptation/adaptasi (A), Goal attaintment/pencapaian tujuan (G), Integration/integrasi (I) dan Latent pattern maintenance/Pemeliharaan polapola laten (L) sering disebut AGIL.

Sedangkan pengembangan perilaku diartikan upaya atau strategi melalui perencanaan, pemetaan, pelaksanaan dalam rangka mengembangkan perilaku negatif menjadi perilaku positif di masyarakat terkait pemilihan septic tank di permukiman kota Banjarmasin, dengan memperhatikan aspek SWOT seperti tabel berikut. 
Tabel 1. Matrik Aspek SWOT Pengembangan Perilaku Pemilihan Septic Tank di Permukiman Kota Banjarmasin

\begin{tabular}{|c|c|c|c|}
\hline Strenght / Kekuatan & Weakness / Kelemahan & Opportunity / Kesempatan & Threath / Ancaman \\
\hline $\begin{array}{l}\text { - Adanya peraturan-peraturan daerah } \\
\text { kota Banjarmasin yang mengatur } \\
\text { tentang pengelolaan limbah termasuk } \\
\text { pengelolaan tinja. } \\
\text { - Adanya PD-PAL dengan } 7 \text { unit IPAL di } \\
\text { Kota Banjarmasin. } \\
\text { - Adanya septic tank komunal yang } \\
\text { dibangun pemerintah kota } \\
\text { Banjarmasin. } \\
\text { - Adanya percontohan septic terapung } \\
\text { yang dibangun pemerintah kota } \\
\text { Banjarmasin. } \\
\text { - Sebagian besar warga telah } \\
\text { menggunakan closet leher angsa. } \\
\text { - Seluruh warga telah menggunakan } \\
\text { - Aumber air PDAM. } \\
\text { - Adanya teknologi yang dapat } \\
\text { mengelola tinja di daerah rawa. }\end{array}$ & $\begin{array}{l}\text { - Kebiasaan menggunakan septic } \\
\text { tank yang tidak kedap air. } \\
\text { - Sebagian besar kondisi rumah } \\
\text { selalu tergenang air. } \\
\text { - Jumlah IPAL milik PD-IPAL belum } \\
\text { mencakup keseluruhan } \\
\text { Kecamatan di kota Banjarmasin. } \\
\text { - Jumlah septic tank komunal yang } \\
\text { dibangun belum mencakup } \\
\text { keseluruhan kecamatan } \\
\text { - Jumlah septic tank terapung } \\
\text { sebagai percontohan tidak } \\
\text { tersebar di seluruh kecamatan. } \\
\text { - Sikap masyarakat bersifat negative } \\
\text { (tidak mendukung) ke arah } \\
\text { perubahan pengelolaan tinja. } \\
\text { - Pendapatan masyarakat masih } \\
\text { banyak kurang dari Rp. } 1 \\
\text { juta/bulan. }\end{array}$ & $\begin{array}{l}\text { - Adanya septic tank portable terbuat } \\
\text { dari fiberglass dijual di pasaran. } \\
\text { - Biaya dan harga pemasangan jenis } \\
\text { septic tank tripikon lebih rendah dari } \\
\text { septic tank konvensional. } \\
\text { - Adanya septic tank yang dibuat dari } \\
\text { kayu ulin. } \\
\text { - Mengurangi pencemaran bakteriologis } \\
\text { pada badan air. } \\
\text { - Mengurangi kemungkinan terjadinya } \\
\text { penularan penyakit berbasi air } \\
\text { (waterborne diaseases). } \\
\text { - Adanya biaya gratis pemasangan } \\
\text { saluran ke PD-PAL serta biaya } \\
\text { operasional selama } 6 \text { bulan ditiadakan } \\
\text { bagi pelanggan baru. } \\
\text { - Adanya peningkatan cakupan } \\
\text { pelayanan PD-PAL sampai minimal } 7 \% \text {. }\end{array}$ & $\begin{array}{l}\text { - Cakupan pelayanan PD-PAL kota } \\
\text { Banjarmasin masih rendah }<6 \% \text {. } \\
\text { - Perkembangan pembangunan } \\
\text { rumah/permukiman baru. } \\
\text { - Peningkatan beban pencemaran akibat } \\
\text { penambahan septic tank yang tidak } \\
\text { saniter terus bertambah. } \\
\text { - Peningkatan kemungkinan terjadinya } \\
\text { penularan penyakit berbasis air } \\
\text { (waterborne diseases). } \\
\text { - Penyebaran pencemaran bakteriologis } \\
\text { saat terjadi pasang terdalam. }\end{array}$ \\
\hline
\end{tabular}

Kekuatan dan kelemahan merupakan faktor internal, sedangkan kesempatan dan ancaman merupakan faktor eksternal. Dalam menggunakan SWOT dapat dilakukan beberapa strategi alternatif penggunaan dengan beberapa kombinasi sebagai berikut: Strategi SO (Strenght-Opportunity) adalah strategi untuk memanfaatkan seluruh Strenght/Kekuatan (S) yang dimiliki untuk merebut Opportunity/Kesempatan (0) sebesarbesarnya. Strategi ST (Strenght-Threath) adalah strategi yang dibuat berdasarkan Strenght/Kekuatan (S) yang dimiliki untuk mengantisipasi atau menghadapi Threath/Ancaman (T) dan berusaha maksimal menjadikan ancaman sebagai Opportunity/Kesempatan (0). Strategi WO (Weakness-Opportunity) adalah strategi diterapkan berdasarkan pemanfaatan Opportunity/Kesempatan (0) yang ada dengan cara meminimalkan Weakness/Kelemahan (W) dan Strategi WT (Weakness-Threath) adalah strategi yang ddasarkan pada kegiatan yang bersifat defensif, berusaha meminimalkan Weakness/ Kelemahan (W) serta sekaligus menghindari dari Threath/Ancaman (T).

Analisis matriks keterkaitan diantara ke 4 (empat) aspek Strenght/Kekuatan, Weakness/Kelemahan, Opportunity/Kesempatan dan Threath/Ancaman ditunjukkan pada tabel berikut : 
Tabel 2. Matriks Analisis SWOT Pengembangan Perilaku Masyarakat Dalam Pemilihan Septic Tank di Permukiman Kota Banjarmasin

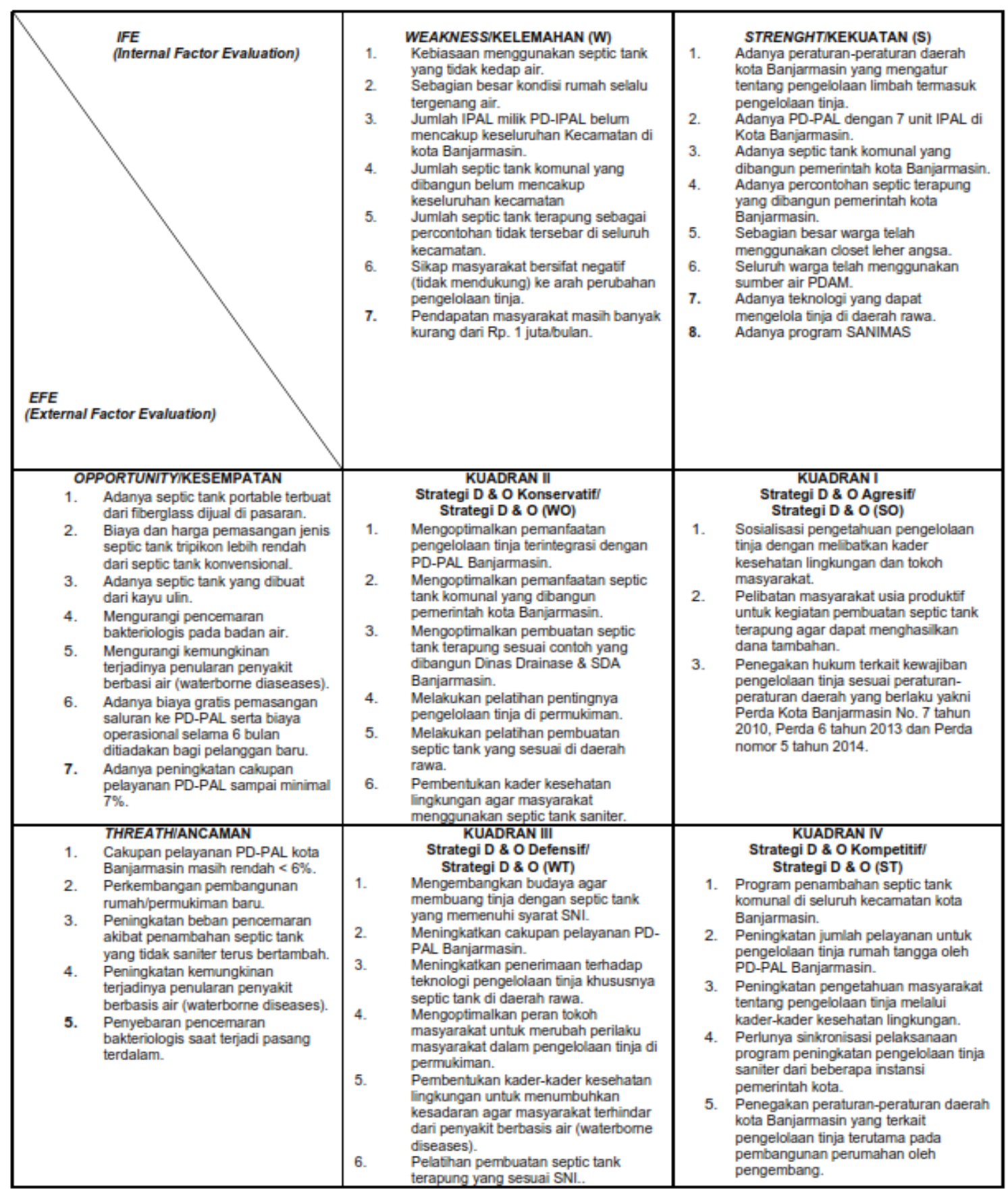

Konsep pengembangan perilaku dalam pemilihan septic tank di permukiman kota Banjarmasin dilakukan analisis melalui matriks SWOT. Aspek SWOT meliputi (S) kekuatan, (W) kelemahan, (O) kesempatan dan (T) ancaman saling terkait satu sama lain, untuk menghasilkan strategi yang sesuai diperlukan penilaian (pembobotan) dengan menggunakan analisis IFAS (Internal Factor Analysis Strategy)- EFAS (External Factor Analysis Strategy) untuk penentuan strategi pengembangan perubahan perubahan perilaku. Hasil dari penilaian (pembobotan) itu ditampilkan dalam bentuk kuadran yang menentukan strategi pengembangan perubahan perubahan perilaku tersebut. 
Berdasarkan perhitungan bobot dan rating untuk faktor internal dan eksternal dihitung, hasilnya dimasukkan ke dalam kuadran SWOT dengan cara : Nilai kuadran sumbu $\mathbf{X}=$ total nilai bobot $\mathrm{X}$ rating Kekuatan $(\mathrm{S})$ + dengan total nilai bobot Kelemahan (W), Sedangkan untuk nilai kuadran sumbu $\mathbf{Y}=$ total nilai bobot $\mathrm{x}$ rating Kesempatan $(0)+$ dengan total nilai bobot x rating Ancaman (W).

\section{Nilai kuadran sumbu $X=1.65+(-0.98)=\mathbf{0 . 6 7}$ \\ Nilai kuadran sumbu $Y=1.25+(-1.32)=\mathbf{- 0 . 0 7}$}

Sehingga gambaran strategi pengembangan perubahan perilaku masyarakat dalam pemilihan septic tank di permukiman kota Banjarmasin berada pada kuadran IV seperti gambar berikut.

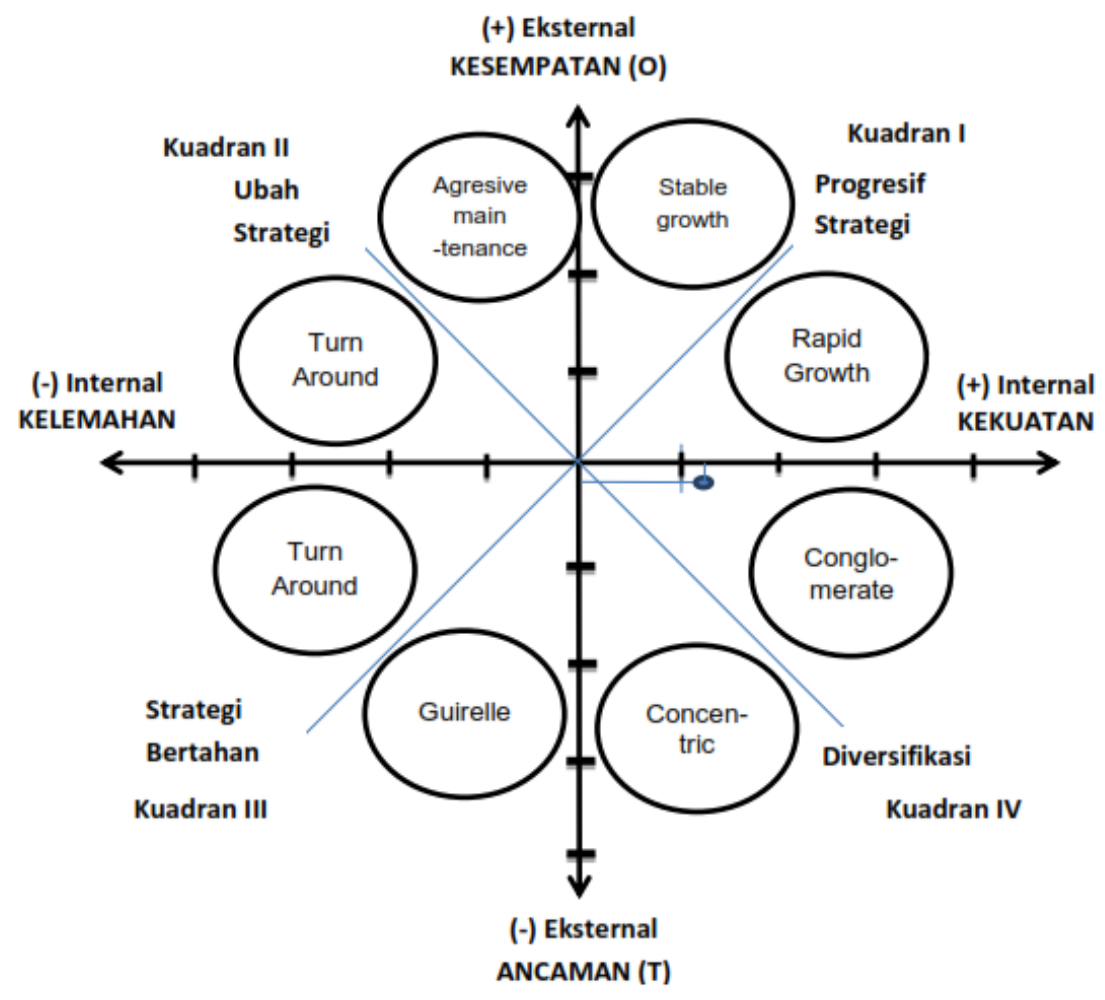

Gambar 1. Kuadran Strategi Analisis IFAS-EFAS Pengembangan Perubahan Perilaku

Berdasarkan hasil analisis seperti gambar diatas pengembangan perilaku masyarakat dalam pemilihan septic tank di permukiman kota Banjarmasin berada pada kuadran IVmenurut matriks grand strategy termasuk dalam conglomerate diversificationstrategy yakni strategi menambahkan upaya baru yang tidak berkaitan dengan sebelumnya, dengan melakukan diversifikasi artinya walaupun warga masyarakat permukiman kota Banjarmasin memiliki ancaman dalam pengelolaan tinja tetapi juga memiliki kekuatan internal. Rekomendasi strategi yang diberikan adalah diversifikasi strategi, artinya organisasi dalam kondisi mantap namun menghadapi sejumlah tantangan berat sehingga diperkirakan roda organisasi akan mengalami kesulitan untuk terus berputar bila hanya bertumpu pada strategi sebelumnya. Oleh karena, organisasi disarankan untuk segera memperbanyak ragam strategi taktisnya.

Berdasarkan hasil analisis pengembangan perilaku masyarakat dalam pemilihan septic tank di permukiman kota Banjarmasin berada pada kuadran IVmenurut matriks grand strategy termasuk dalam conglomerate diversification strategy yakni strategi menambahkan upaya baru yang tidak 
berkaitan dengan sebelumnya, dengan melakukan diversifikasi artinya walaupun warga masyarakat permukiman kota Banjarmasin memiliki ancaman dalam pengelolaan tinja tetapi juga memiliki kekuatan internal. Rekomendasi strategi yang diberikan adalah diversifikasi strategi, artinya organisasi dalam kondisi mantap namun menghadapi sejumlah tantangan berat sehingga diperkirakan roda organisasi akan mengalami kesulitan untuk terus berputar bila hanya bertumpu pada strategi sebelumnya. Oleh karena, organisasi disarankan untuk segera memperbanyak ragam strategi taktisnya.

Strategi pengembangan perilaku masyarakat dalam pemilihan septic tank di permukiman kota Banjarmasin diperlukan waktu jangka panjang mengingat perubahan perilaku adalah sebuah evolusi, dengan strategi diversifikasi yaitu: 1). Penegakan peraturan-peraturan daerah yang telah mengatur terkait pengelolaan limbah termasuk pengelolaan tinja yakni Peraturan Daerah Kota Banjarmasin nomor 7 tahun 2010 tentang ijin pembuangan dan pengolahan limbah cair; 2). Pengembangan perubahan perilaku dimulai dari perubahan pengetahuan, sikap dan akhirnya perubahan tindakan dalam pengelolaan tinja; 3). Melakukan pengorganisasian masyarakat sesuai dengan keinginan sebagian besar masyarakat agar ada organisasi khusus yang mengorganisir pembuangan tinja di permukiman kota Banjarmasin; 4). Menawarkan sistem arisan jamban (septic tank) bagi warga masyarakat yaitu dengan cara menambahkan sistem arisan ini ke dalam perkumpulan Yassinan mingguan pada warga masyarakat Banjarmasin; dan 5). Pembuatan septic tank tripikon dan atau septic tank terapung dari bahan lainnya misalnya dari tandon air berbahan fiber glass (seperti yang sudah dicontohkan oleh Dinas Drainase dan Sumber Daya Air Kota Banjarmasin).

Jika pemasangan septic tank dengan bahan dasar kubus terbuat dari kayu ulin tersebut dimodifikasi agar memenuhi syarat, diperlukan keahlian khusus untuk dapat melakukan pengecoran dengan menggunakan semen ke seluruh bagian agar menjadi kedap air, pekerjaan ini akan semakin sulit mengingat posisi septic tank berada di dalam air. Pada septic tank yang sudah terpasang hal ini tidak dapat dilakukan mengingat kondisi lantai septic tank yang sudah terisi tersebut juga harus dibuat menjadi kedap air, sehingga langkah yang lebih realistis adalah memilih salah satu opsi pengelolaan tinjanya yaitu dengan: 1). mengintegrasikan dengan PD-PAL Banjarmasin; atau 2). mengintegrasikan dengan septic tank komunal; atau 2) membangun septic tank individual yang memenuhi syarat SNI dengan pilihan septic tank tripikon/pabrikan terbuat dari fiberglass.

Terkait dengan pengadopsian teknologi inovasi termasuk dalam hal ini penggunaan septic tank terapung dapat dikaitkan dengan teori yang dikemukakan Rogers, memiliki relevansi dan argumen yang cukup signifikan dalam proses pengambilan keputusan inovasi. Teori tersebut antara lain menggambarkan tentang variabel yang berpengaruh terhadap tingkat adopsi suatu inovasi serta tahapan dari proses pengambilan keputusan inovasi. Variabel yang berpengaruh terhadap tahapan difusi inovasi tersebut mencakup (1) atribut inovasi (perceived atrribute of innovasion), (2) jenis keputusan inovasi (type of innovation decisions), (3) saluran komunikasi (communication channels), (4) kondisi sistem sosial (nature of social system), dan (5) peran agen perubah (change agents).

Sementara itu tahapan dari proses pengambilan keputusan inovasi mencakup: 1). tahap munculnya pengetahuan (knowledge) ketika seorang individu (atau unit pengambil keputusan lainnya) diarahkan untuk memahami eksistensi dan keuntungan/manfaat dan bagaimana suatu inovasi berfungsi. 2). tahap persuasi (persuasion) ketika seorang individu (atau unit pengambil 
keputusan lainnya) membentuk sikap baik atau tidak baik. 3). tahap keputusan (decisions) muncul ketika seorang individu atau unit pengambil keputusan lainnya terlibat dalam aktivitas yang mengarah pada pemilihan adopsi atau penolakan sebuah inovasi. 4). tahapan implementasi (implementation), ketika sorang individu atau unit pengambil keputusan lainnya menetapkan penggunaan suatu inovasi. 5). tahapan konfirmasi (confirmation), ketika seorang individu atau unit pengambil keputusan lainnya mencari penguatan terhadap keputusan penerimaan atau penolakan inovasi yang sudah dibuat sebelumnya.

\section{KESIMPULAN DAN SARAN}

Strategi pengembangan perilaku pemilihan septic tank di permukiman kota Banjarmasin berdasarkan analisis SWOT berada pada kuadran IV ruang G sehingga strategi yang digunakan adalah conglomerate diversification strategy melalui perubahan pada faktor predisposisi perilaku terpimpin ke tahap adopsi, faktor pemungkin perubahan pemahaman terkait ketersediaan prasarana dan sarana pembuangan tinja yang sesuai standard dan faktor penguat diperlukan optimalisasi sosialisasi peraturan daerah kota Banjarmasin yang ada terkait pembuangan tinja.

\section{KEPUSTAKAAN}

1. BPS, 2014., Kota Banjarmasin Dalam Angka tahun 2015, BPS Kota Banjarmasin
2. BPS, 2011., Survei Sosial Ekonomi Nasional, Jakarta.

3. Dinkes, 2012., Profil Kesehatan Kota Banjarmasin tahun 2001 - 2011, Dinkes Kota Banjarmasin.

4. Media, Y., Kasnodihardjo, Friskarini, K., 2002.,.Pengetahuan, Sikap dan Perilaku Penduduk Dalam Kaitannya dengan Kesehatan Lingkungan dan Hygiene Perorangan di Kabupaten Subang, Jawa Barat, Jurnal Ekologi Kesehatan, Vol 1. No 1.

5. SNI : 03-2399-2002 Tata Cara Perencanaan Bangunan MCK Umum, www.bsn.go.id.

6. SNI : 03-2398-2002-Tata Cara Perencanaan Tangki Septik dengan Sistem Peresapan, www.bsn.go.id.

7. Glannz, K., Lewis, F.M., Rimer, B.K., 1992, Health Behaviour and Health education Theaory, Research and Practice, Second edition, Jossesy-Bass Publishers, San Fransisco, USA.

8. Hardjoso P., 1994., Tripikon-S Proses di Dalam Tangki, Lab Ex P4S FT UGM, Yogyakarta.

9. Rangkuti, F., 2015, Personal SWOT Analysis, Peluang Dibalik Kesulitan, PT. Gramedia Pustaka Utama, Jakarta.

10. Sher, Muhammad A, Ali., Hasnain, Syed Ali., Iqbal, Syed Rashad, 2012., Socio-economic analysis of the interventions aimed at improving water and sanitation condition of rural community, Research on Humanities and Social Sciences, Vol 2 No 10 , 